\title{
Sense of place and the city: the case of non-native residents in Lisbon
}

\author{
Vicente Tang ${ }^{1}$, Albert Acedo ${ }^{2,3}$, and Marco Painho ${ }^{1}$ \\ ${ }^{1}$ NOVA Information Management School (NOVA IMS), Universidade Nova de Lisboa (UNL), \\ Campus de Campolide, Lisbon, Portugal \\ ${ }^{2}$ Institute of New Imaging Technologies, Universitat Jaume I, Castellón de Plana, Spain \\ ${ }^{3}$ ITI/LARSyS, Instituto Superior Técnico, Universidade de Lisboa, Lisbon, Portugal
}

Received: July 1, 2021; returned: September 6, 2021; revised: October 30, 2021; accepted: November 19, 2021.

\begin{abstract}
When immigrants move to a new city, they tend to develop distinct relationships with the urban landscape, which in turn becomes the new setting of their routine-based activities that evolve over time. Previous works in environmental psychology have quantitatively examined non-native residents' development of sense of place towards their new environment. In this paper, we introduce the spatial perspective into studying the sense of place experienced by non-natives in an urban context. We study the person-place bonds, relationships, and feelings cultivated by non-native residents living in the city of Lisbon (Portugal) through an online map-based survey. Then, we carried out spatial analysis aimed at distinguishing and visualizing the different facets of sense of place developed by two participant groups: short-term residents and long-term residents. Results showed that while short-term residents reported bonds with places, long-term residents' senses of place were more intense and broader throughout the city. The correlations, associations, and relationships between participant groups and the dimensions of sense of place allowed us to observe features and patterns that were previously described in the literature, although adding the spatial lenses can potentially provide better insights for urban planning, community development, and inclusive policies.
\end{abstract}

Keywords: place, sense of place, non-native residents, map-based survey, urban context

\section{Introduction}

The concept of place is intimately connected with how people perceive and communicate about their spatial environment, and it has been explored by several disciplines, such as 
philosophy, psychology, geography and more recently, geographic information science (GIScience) $[10,22,34,38]$. Among many conceptualizations, place has traditionally been approached through comparison, materialized by the space-place dialectics, permeated into discourses that can be traced back to the works of Aristotle [13]. Although different applications and epistemological perspectives yield different concepts for space and place, they complement each other in their definitions. In his book on space and place, the humanistic geographer Yi-Fu Tuan [53] argues that space is more abstract for humans than the concept of place. According to the author, the absolute, objective, coordinate-based geographic space is conceptually more difficult to grasp when compared to the relative, multi-dimensional, subjective, and perceptual perspective that people have of their surroundings. Embracing this viewpoint, we approach the concept of place contextualized as it is in the field of human geography, which carries the nuances of feelings, symbols, perceptions, and meanings that individuals develop towards the geographic world through cognitive, affective, and behavioral mechanisms [54]. Extending the concept of place and grounding on studies in environmental psychology, we conceptualize sense of place as the construct that embeds the bonds, attachments, or relationships that individuals or groups of people foster towards meaningful locations [58].

We must acknowledge that the broad character of the sense of place construct as well as its multidisciplinary nature has let different fields to build conceptual schemes on which several methodological frameworks were developed [8]. There is a multitude of terms in the literature which not only have caused confusion but also have blocked a rapid advance in the research field [23]. As pointed out by Hidalgo and Hernández [23], terms such as community attachment, sense of community, place attachment, place identity, place dependence and sense of place have been studied in environmental psychology in ways that it is hard to discern the conceptual structure underlying these constructs. Nonetheless, the field of environmental psychology has measured and unraveled different dimensions of the construct of place attachment, defined by Scannel and Gifford [48] as the "bonding between the individual and their meaningful environments" (p. 1). In human geography, the concept of sense of place might carry more intricate and complex components that are not easily or necessarily measurable. We have studied the construct of sense of place using dimensions operationalized mostly within environmental psychology, while also supporting our conceptual background and interpretations in light of GIScience and human geography

In a highly globalized, interconnected, and accessible world, the connections, feelings, and relationships between people and places have become the object of study in many research fields [31]. The dynamics of a mobile world are responsible for not only altering existing bonds but also for generating new typologies of people-place connections, as more people are traveling and moving both domestically and internationally [19]. Previous research has shown that people do develop relationships with places which are not necessarily their home country, city, or neighborhood [38]. Examples include individuals who are moving for work or education in search for better life conditions, refugees, people who own recreational homes, and people who constantly travel to the same location [20]. There are several social and cultural studies investigating the process of adaptation of non-native residents, but the spatial perspective on this process has gained less attention. GIScience and its tools (e.g., public participatory geographic information systems) have been employed in the literature to examine the spatial dimension of sense of place and other constructs, such as social capital and civic engagement $[1,10]$. In addition to its spatial component, it has been observed that time is one of the most important factors to modulate sense of 
place [46], as it permits new residents to foster adaptation, exploration and engagement in new environments [41]. In light of this, this study intends to introduce a unique angle to spatially collect, explore and assess person-place relationships that build up the construct of sense of place in the context of non-native residents in a new urban setting.

Natives are expected to have matured stronger sense of place bonds than non-native residents because they were born and raised within the in situ cultural context [60]. Nonnative residents' development of sense of place is highly dependent on the length of residence, and the distinct bonds with their new places are cultivated within different time periods and with different intensities [22]. Although there are several types of migration and mobility patterns that depend on economic, social, and cultural motives (e.g., tourism, long-term residence, holiday home ownership, highly skilled migration, forced migration, etc.), large urban areas around the world have always attracted newcomers seeking new life opportunities and experiences [25]. The motivation behind our study stems from the contribution that mapping sense of place of non-native urban residents can provide. We use the term non-native resident in this paper to refer to an individual who lives in a community or city in which they were not born and raised [60]. In our study, non-native urban residents are also foreign individuals, thus not including people that were born in the same country and moved to a new city. In a broader perspective, spatializing this construct can help better understand the relationships between other concepts that are closely related to places and community dynamics, such as sense of community and social capital [2]. Within the context of non-native residents, spatializing such concepts is a step towards holistic participatory planning because it informs and complements the community planning process as well as it fosters partnerships between different groups for finding common interests in their neighborhoods' improvement and individual well-being [35]. As non-native residents might feel underrepresented or not fully integrated into the city, acknowledging and identifying their sense of place towards the city is one way of giving them a sense of control, empowerment and inclusion.

This paper aims at applying a map-based survey and a set of spatial analysis methods to describe and discern the spatial patterns of sense of place developed by non-native residents within an urban landscape. In other words, we aim at exploring and assessing the spatial dimension of the feelings, perceptions, and relationships that non-native residents have towards their current city of residence. Specifically, our study provides a methodology to evaluate the process of creating sense of place from a spatial perspective through contrasting short-term and long-term non-native residents (we also refer to the groups as short-terms and long-terms respectively throughout the paper). The straightforward methodology we applied can potentially be implemented to other social-spatial constructs. We first set the theoretical foundations of the sense of place construct for nonnative residents and then, in the context of GIScience, we sought to obtain useful insights regarding the spatial distribution of sense of place in the city. By conducting a case study in Lisbon (Portugal), the main objective of this study is to frame methods aimed to: (i) explore and characterize the spatial extent of sense of place developed by non-native residents; (ii) compare the spatial patterns of the dimensions of sense of place between short-term and long-term non-native residents; (iii) identify places in the city where residents collectively feel sense of place while discussing the plausible mechanisms that cause distinctions between and within groups.

The remainder of this paper is structured as follows. In Section 2, we present the relevant literature on the topic. Section 3 brings forward the conceptual framework we used 
to frame our study whereas in Section 4 our methods are explained. Section 5 presents the results of our survey and analysis. Then, we present our final discussion on Section 6 and concluding remarks on Section 7.

\section{Background}

In his seminar work on place studies within human geography, Yi-Fu Tuan [53], defined sense of place as a "universial affective tie that fulfills fundamental human needs." People develop sense of place over time based on meanings attributed to the settings as the construct is not attached only to the physical world, but lies on the symbolic representations people have towards places through experience and interaction [51]. Sense of place grows and mature from the interplay of visual, historical, psychological, environmental, social, and even spiritual factors. Hence, the construct can be broad and multifaceted, enabling its breakdown into components or dimensions. When interpreting the concept, Vanclay [55] cited the definition retrieved from a report of the Australian government: "an intensely personal response to the environment, social and natural, which the individual experiences in daily life, at a broader level it can be the individual's perception of the whole region, state or nation." The literature has approached sense of place both conceptually and operationally as a multidimensional construct, able to contain various aspects of how people establish relationships with places. In their pioneering study, Jorgensen and Stedman [27] brought forward the existence of three dimensions: place attachment, place dependence, and place identity, each corresponding respectively to the affective, behavioral, and cognitive qualities of the construct. The authors set the ground for research agendas that aimed at either describing these dimensions or at unraveling other components of the concept [31]. From then on, studies on sense of place from different disciplines have been exploring and unfolding the several facets the construct can hold [8,9,14,44,45].

Previous research has also confirmed the influence of time in the development of sense of place, in addition to other factors regarding demographic, physical, cultural, and linguistic variables $[27,47,56-58]$. The time spent living or visiting a place allows spatial knowledge to increase, enabling people to not only acknowledge their environment, but also to obtain more information, fomenting the development of new feelings towards new places [30]. However, most of the previous studies have collected data from native residents who had been living in the same city or country for most of their lives. As pointed out by Hernández et al. [22], when looking at the different facets of sense of place, usually natives had significantly developed all the distinct dimensions of the construct. According to their study, this causes the different components of sense of place to show higher correlation and overlap, whereas non-native residents generally report stronger discrepancies among the separate types of bonds or relationships. Nonetheless, newcomers do establish relationships with new places that stem from immediate perceptions, while other feelings might take longer to grow than others, and thus initial judgments and the length of residence seem to have a strong influence in shaping sense of place $[46,52]$.

While sense of place is a psychological construct, it is fundamentally attached to a geographic dimension [4]. The fields of human geography and environmental psychology have extensively discussed the concept, but GIScience has not solidified spatial approaches to investigate sense of place. Before merging sense of place and geographical information, the spatial dimension was only considered as a scale of attachment, such as the house,

www.josis.org 
apartment, neighborhood, city, or country [30]. Later, efforts in spatializing the concept through the lenses of geographical information started to be carried out, such as the works of Brown and colleagues [8-10]. They contributed to filling the gap by applying geographic information systems (GIS) and spatial analysis in studying collective sense of place in the scope of natural resource management. Another example is the study conducted by Jenkins et al. [26], in which the authors collected geotagged data from social media and Wikipedia to analyze the sense of place of the users in different cities. They characterized their study as a contribution to shifting from the mere geometric perspective of the environment to a place-based viewpoint through understanding how citizens and visitors understand the building blocks of the city. More recently, Acedo et al. [1] developed a web-based platform that enabled users to draw polygons according to their personal areas of sense of place, social capital and civic engagement in the city of Lisbon, allowing further visualization and analysis. Their conceptual framework integrated the three constructs, and from which subsequent analysis brought forward contributions to the field through accounting for the constructs' spatial dimensions within the urban landscape [3-5].

In the context of sense of place matured by non-native residents, literature has often treated mobility and sense of place as opposite or exclusive phenomena [49]. Nonetheless, people who are more mobile develop relations with places by creating meaning through different processes when compared to native residents $[19,22]$. The methods used to investigate sense of place of different groups and profiles of non-native residents usually consist of questionnaires and in-depth interviews, aimed at distinguishing the dimensions of sense of place and their evolution $[15,22,36,37,40,52]$. Hence, research on non-native residents seems to be consolidated outside spatial or geographic information science, which in turn creates an opportunity to use geospatial technologies and principles to introduce a new point of view to the study of sense of place experienced by this specific demographic profile.

\section{Conceptual framework}

In order for us to better describe and represent the spatial distributions of sense of place fostered by non-native residents, we have chosen to treat the construct as multi-dimensional. The different dimensions of sense of place are framed and supported by the existing literature in an attempt to have a finer theoretical resolution of analysis and interpretation. There are several migration patterns with different aspects regarding voluntary choices, undertaken activities and intent of settling down in the new place, which in turn shape non-natives' experiences in and perceptions of their place of residence [22]. Nonetheless, the goal of our study was to understand how distinctions on residence time can cause distinctions on sense of place within non-native residents through the spatial perspective in general. We acknowledge that sense of place develops differently based on age, social and cultural capital, family situation as well as socioeconomic characteristics [52], yet our approach can be tailored to more specific participant groups and migration contexts. In addition, inferences regarding the migration profiles of participants can also be drawn based on the identification and further interpretation of specific places in the city where sense of place is shared among non-native residents. Lastly, research has shown that adverse conditions such as low levels of financial or housing security do not seem to prevent 
the development of sense of place and place attachment, although lower satisfaction and quality of life can indeed slow down the process [30].

We employed a four-dimensional model of sense of place as our conceptual framework aimed at framing the survey, the analysis and the interpretation of the findings (Table 1). The structure of the model is based on the four dimensions identified by Trabka [52] when investigating how distinct facets of sense of place emerged and evolved among voluntary polish immigrants living in Oslo and London through the use of semi-structured in-depth interviews. Through a thorough qualitative analysis, the author identified four dimensions: place dependence-related to perceived affordances and new opportunities; place discovered-sense of mastery and pleasure from exploring places; place identityregarding the arena of self-expression; and place inherited-dimension that bridges places and social ties as well as life-shaping experiences. We acknowledge that the context of Trabka's study is specific to a certain profile of international migration, but we have applied and adjusted the model to our implementation due to two main reasons. First, the study conducted by Trabka contemplated aspects that are pertinent to our implementation, such as: the dimensions were considered to be dynamic both in space and time; the length of residence influenced the development of the dimensions; the bonds and activities concerned the urban context; the participants were non-native residents living in a new city at the time; dimensions are not necessarily developed sequentially and some might not develop at all. Second, a four-dimensional model seems to better capture the spectrum of dimensions that start from functional, behavioral, physical and cognitive aspects of places and head towards more emotional, social and rooted relationships with places.

As seen in Table 1, we present the definitions for each dimension of sense of place based on the conceptualizations and studies found in the literature mostly within environmental psychology and human geography $[11,22,27,33,48,49,52,55]$. Place dependence and place identity are well consolidated dimensions both in quantitative and qualitative studies on environmental psychology. In Trabka's [52] original model, place inherited and place discovered are dimensions that correspond to deeper emotional bonds and active place attachment respectively [32]. Nonetheless, we reinterpreted the dimension of place discovered and designated it as place awareness, a facet of sense of place found in other articles [55] that considers the exploration of places as well as the cognitive familiarity with new areas, representing a transition within the functional to emotional attachment spectrum.

\begin{tabular}{ll}
\hline Dimensions & Definitions \\
\hline Place dependence & $\begin{array}{l}\text { Functional attachment based on the affordances, opportunities, amenities, and resources } \\
\text { places can provide for goal-oriented behavior. Aspects include daily tasks, physical activ- } \\
\text { ity, leisure, entertainment, working, and studying }\end{array}$ \\
\hline Place awareness & $\begin{array}{l}\text { Dimension related to knowledge and familiarity. The bond stems from a combination of } \\
\text { cognitive aspects such as navigational skills and emotional aspects, including enjoyment } \\
\text { and pleasure from exploring new places }\end{array}$ \\
\hline Place identity & $\begin{array}{l}\text { Emotional attachment developed when places acquire symbolic meanings and could be- } \\
\text { come part of self-identity. Frequent or habitual interactions in and with places can foster } \\
\text { this bond }\end{array}$ \\
\hline Place inherited & $\begin{array}{l}\text { Deeper attachment related to feelings of rootedness and belonging. Significant social inter- } \\
\text { actions, life-shaping events and family ties can foster this relationship. The bond is poten- } \\
\text { tially matured in the long-term }\end{array}$ \\
\hline
\end{tabular}

Table 1: The four dimensions of sense of place analyzed in this study. 


\section{Methodology}

We employed a twofold methodology: a map-based survey for data collection and the following analysis of the gathered data. We carried out the study in the municipality of Lisbon, Portugal. The city of Lisbon is an ideal candidate for implementing our analysis due to several reasons: its growing international significance in innovative industries, which has been attracting high-skilled foreign workers; its increasing number of international students in higher education; its fast-changing urban landscape, partly a product of tourism-oriented public policies, and lastly, its diversity regarding the socio-economic profiles of international migrants $[6,17,42]$. These reasons turn Lisbon into a city where nonnatives are willing to actively interact with their urban environment, engaging in different activities in the social, economic, and cultural spheres. Lastly, we must clarify that only non-native (non-Portuguese) residents of the city of Lisbon were allowed to participate in the survey.

\subsection{Map-based survey}

We designed the survey to obtain data about each dimension of sense of place (Table 2). Each section of the survey corresponded to each dimension of the construct described in our conceptual framework. A section consisted of two parts: initially, we incited the participants to think about specific places according to the respective dimension, then we asked them to draw the areas in the city that would answer a set of specific questions; secondly, we presented one statement that reinforced the relationship between the participants and the areas they had just drawn. The participants had to select an option from a 4-point Likert scale consisting of neutral, partly agree, agree and strongly agree. We used the answers to the scale-based questions to input into the analysis additional information regarding the intensity of the person-place relation towards the outlined areas. In our case, a 4-point scale seemed more appropriate as the first element of the scale was the option "neutral".

The first section of the survey was compulsory since the dimension of place dependence represents daily tasks, activities and routine-based place interactions. In addition, we asked participants information about their postal codes in order to confirm if they were living within Lisbon's municipality at the time. We implemented the survey through ESRI's application Survey 123 [16] and added introductory information about the study, recommendations, contact details and data terms. Following the introduction, we asked participants to fill in their time of residence in the city based on three options: less than six months; between six months and one year; and more than one year. Although participants were later split into two groups, we originally set the three time periods to enable a finer time resolution depending on the number of survey respondents, such as: recent shortterm, short-term and long-term residents. For each main section of the survey, respondents would be asked to freely delineate polygons onto a base-map of Lisbon. The polygons were drawn to answer a set of two questions corresponding to the areas where each dimension of sense of place was felt within the city (Figure 1).

We first shared the final version of the survey with different office representatives and course coordinators of NOVA Information Management School at the NOVA University Lisbon. Our instructions to the university staff included sharing the survey with non-native (non-Portuguese) students, researchers and other staff of the school. We also reached out to other educational and non-educational institutions and organizations at the municipal 


\begin{tabular}{|c|c|c|c|}
\hline Dimension & Introduction & Map-based questions & Likert scale statement \\
\hline \multirow[t]{2}{*}{$\begin{array}{l}\text { Place } \\
\text { dependence }\end{array}$} & $\begin{array}{l}\text { Think about the places in which } \\
\text { you perform most of your daily } \\
\text { tasks such as working, studying, } \\
\text { doing groceries, exercising, etc. }\end{array}$ & $\begin{array}{l}\text { Where are the areas you perform } \\
\text { most of your daily tasks? }\end{array}$ & $\begin{array}{l}\text { The places I chose are the most } \\
\text { suitable for providing the condi- } \\
\text { tions and resources for my activ- } \\
\text { ities }\end{array}$ \\
\hline & $\begin{array}{l}\text { In addition, also think about the } \\
\text { best places for doing the activities } \\
\text { you enjoy such as hobby, entertain- } \\
\text { ment and, leisure related activities }\end{array}$ & $\begin{array}{l}\text { Where are the best areas for do- } \\
\text { ing the activities that you like? }\end{array}$ & \\
\hline \multirow[t]{2}{*}{$\begin{array}{l}\text { Place } \\
\text { awareness }\end{array}$} & $\begin{array}{l}\text { Now think about the areas in } \\
\text { the city which you have acquired } \\
\text { knowledge about. Areas where } \\
\text { you know how to get around eas- } \\
\text { ily and places which you wish to } \\
\text { know more }\end{array}$ & $\begin{array}{l}\text { Where are the areas you know } \\
\text { how to get around easily without } \\
\text { using routing applications? }\end{array}$ & $\begin{array}{l}\text { I enjoy exploring and getting to } \\
\text { know more about the places I } \\
\text { chose }\end{array}$ \\
\hline & $\begin{array}{l}\text { Are there places that you know } \\
\text { about their history, evolution, cul- } \\
\text { ture or even curiosities? Are there } \\
\text { places that you enjoy exploring? }\end{array}$ & $\begin{array}{l}\text { Where are the areas you like to } \\
\text { explore and discover or would } \\
\text { like to do so? }\end{array}$ & \\
\hline \multirow[t]{2}{*}{$\begin{array}{l}\text { Place } \\
\text { identity }\end{array}$} & $\begin{array}{l}\text { Think about the places in the city } \\
\text { of Lisbon which you are emotion- } \\
\text { ally attached to. Are there any ar- } \\
\text { eas that you can say represent you? }\end{array}$ & $\begin{array}{l}\text { Where are the areas you have a } \\
\text { special bond with? }\end{array}$ & $\begin{array}{l}\text { The places I chose reflect my per- } \\
\text { sonality in some way }\end{array}$ \\
\hline & $\begin{array}{l}\text { Are there any places that matches } \\
\text { with your personality? }\end{array}$ & $\begin{array}{l}\text { Where are the areas that repre- } \\
\text { sent your lifestyle? }\end{array}$ & \\
\hline \multirow[t]{2}{*}{$\begin{array}{l}\text { Place } \\
\text { inherited }\end{array}$} & $\begin{array}{l}\text { In this last section, think about the } \\
\text { places you feel deeply attached to } \\
\text { because you are grounded in them. } \\
\text { Are there places you created roots } \\
\text { in because of a partner, a group of } \\
\text { close friends or even new family } \\
\text { ties? }\end{array}$ & $\begin{array}{l}\text { Where are the areas you feel you } \\
\text { belong to because you created } \\
\text { roots? }\end{array}$ & $\begin{array}{l}\text { I am deeply attached to the places } \\
\text { I chose }\end{array}$ \\
\hline & $\begin{array}{l}\text { Are there places to which you feel } \\
\text { you belong? Are there any places } \\
\text { in which you had experiences that } \\
\text { have shaped your life as it is now? }\end{array}$ & $\begin{array}{l}\text { Where are the areas in which you } \\
\text { had life-shaping experiences? }\end{array}$ & \\
\hline
\end{tabular}

Table 2: Questions and introductions of each dimension of sense of place assessed in the survey.

level, although only the Instituto Superior Técnico (IST) replied and notified that they actively shared the survey among their non-native researchers and students. Throughout the process, participants were encouraged to share the survey link with friends, family and acquaintances, as long as they were non-native residents living in Lisbon at the time. The survey was made available online for approximately three weeks. Although we did not gather information on participants' occupation, the sampling strategy and further results allowed us to assume that a significant percentage of respondents were either students or worked at the two universities (see 5.2), which in turn partially framed our discussions and potential contributions. As we have elucidated, our four-dimensional model was not specifically tailored to a certain migrant or foreign resident profile but structured to represent the spectrum of people-place relationships that individuals might experience as being non-native residents within a given city. Therefore, we provide a generalist framework that can be further adjusted to specific topics and sampling strategies to support studies on specific participant profiles.

www.josis.org 


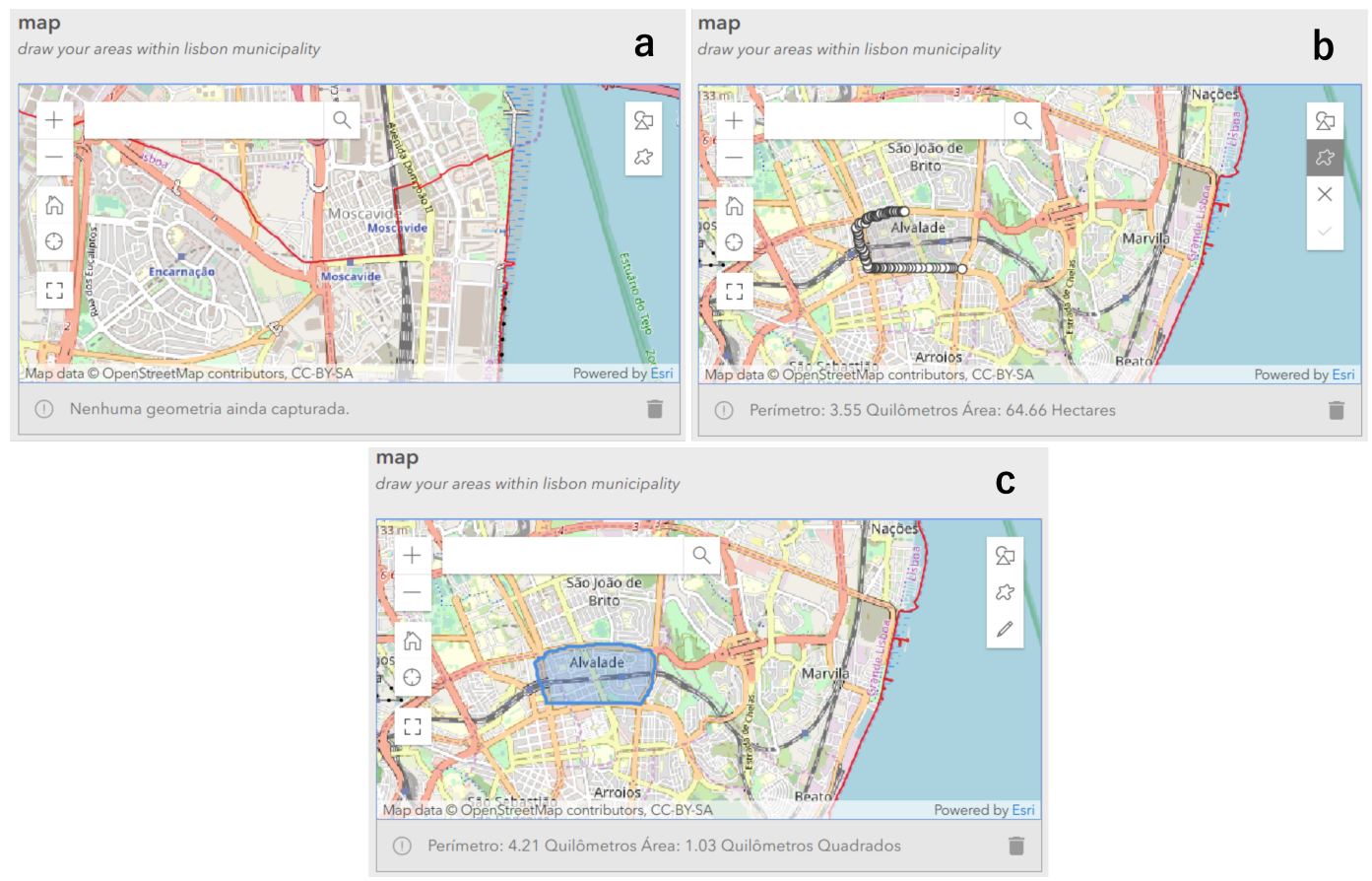

Figure 1: Drawing polygons on the survey: (a) Lisbon's municipality perimeter as the red line; (b) freehand option; (c) final polygon.

After collecting the data and prior to the analysis, we converted the neutral-strongly agree Likert scale responses to numerical attributes, with the objective of assigning integer values to the drawn polygons. In other words, the higher the agreement to the statement, the higher the value attributed to the polygon (in equal intervals, with neutral not being null) and the stronger the bond felt by the participant with the outlined areas for a specific dimension of sense of place. This type of conversion requires assumptions regarding data distribution and other external variables specific to the context, which would ultimately define the most suitable conversion algorithm [59]. However, our goal was to obtain additional information on the intensity of the bond, but drawn polygons themselves already represent the existence of this relationship as they were outlined according to a specific set of questions. Furthermore, when overlaying polygons to calculate overlapped areas of sense of place between participants, values of overlap did not represent the simple sum of polygon count, but the sum of their intensity numerical values converted from the Likert scale answers.

Lastly, we split the data based on the participants' time of residence in the city to assess the differences between short-term and long-term residents. In our case, we used a oneyear threshold: short-terms (short-term residents) were individuals who had been living less than a year in Lisbon, whereas long-terms (long-term residents) had been living more than a year in the city. The survey was originally designed aiming at splitting non-native residents into three groups consisting of those who might have developed an embryonic 
sense of place, those who might have a more solid sense of place, and those who might have consolidated more matured relationships with places, regardless of the varying degrees of development within the latter. Nonetheless, we acknowledge the arbitrariness of the threshold used to split the participants as well as to define the answer options in the survey.

\subsection{Analysis}

The steps and tasks we carried out to analyze the data collected from the survey are described as follows:

- Overlay and hotspot analysis: polygons were first aggregated to apply overlay analysis, aimed at quantifying polygon overlap or density. Therefore, the strength of each dimension of sense of place for each participant group was represented by the spatial concurrence of drawn polygons, areas with shared regions of sense of place among residents. We then normalized the results and transferred them to a hexagonal mesh. Subsequently, we conducted hotspot analysis using the Getis-Org $\mathrm{Gi}^{*}$ algorithm, followed by the selection and extraction of areas carrying high-value hotspots with $99 \%$ confidence ( $p$-value $<0.01$ and z-score $>2.48$ ). We utilized ArcGIS Pro software to carry out both overlay and hotspot analysis.

- Spatial metric and Jaccard's index: we implemented the Spatial Efficiency metric (SPAEF) developed by Koch et al. [28] with the goal of obtaining scores for spatial pattern comparison between the distribution of sense of place among participants. The rationale that supports the use of this metric lies in the fact that first, collective sense of place is treated here as a continuous phenomenon spread across the urban landscape. Although we discretize sense of place when selecting and categorizing regions for the sake of identification and measurement (e.g., Jaccard's index), our assumption is that the strength of shared sense of place is represented by a continuum over the city. On a second note, we acknowledge that SPAEF was originally developed for modeling earth's systems, yet Koch et al. [28] demonstrated that the metric is straightforward in the attempt of not only dealing with the non-trivial task of quantifying spatial similarity, but also of conceiving easily interpretable measurement values. Therefore, we found SPAEF to be an adequate and a novel approach in identifying overall spatial pattern comparison in our study, with the objective of providing a simple method for spatial distribution assessment of continuous surfaces. The metric algorithm is built based on three equally weighted parameters: Pearson correlation, ratio of coefficient of variation and histogram overlap. We applied the algorithm using Python to measure the spatial similarity between the dimensions of the construct between participant groups as well as between dimensions themselves. The metric equation (modified from [28]) is expressed as:

$$
S P A E F=1-\sqrt{(\alpha-1)^{2}+(\beta-1)^{2}+(\gamma-1)^{2}}
$$

where:

$$
\alpha=\rho(a, b), \beta=\frac{\left(\frac{\sigma_{b}}{\mu_{b}}\right)}{\left(\frac{\sigma_{a}}{\mu_{a}}\right)}, \gamma=\frac{\sum_{j=1}^{n} \min \left(K_{j}, L_{j}\right)}{\sum_{j=1}^{n} K_{j}}
$$

www.josis.org 
Where $\mathrm{a}$ and $\mathrm{b}$ are the patterns to be compared; $\alpha$ is the Pearson correlation coefficient between the patterns; $\beta$ is the ratio of coefficient of variations of each pattern (spatial variability) and $\gamma$ is the histogram intersection, while $\mathrm{K}$ and $\mathrm{L}$ are the corresponding histograms and $n$ the bin count. Pattern similarity is defined by the Euclidean distance to the optimal point $(1,1,1)$, the highest score for each parameter.

\section{Results and initial discussion}

\subsection{Survey}

In total, 81 participants answered the survey, from which 45 had been living in Lisbon for less than six months, 6 had been living in the city between six months and one year, and 30 respondents had been living for more than one year. Therefore, based on the one-year threshold set for our analysis, short-term residents consisted of 51 individuals whereas 30 individuals were categorized as long-term residents. For those who shared their residence area, most of the postal codes lay within central areas of the municipality, except for four participants whose residence locations were placed outside the city, yet still in Lisbon's metropolitan region. The response rate was the following: for short-term residents, $100 \%$, $80 \%, 69 \%$, and $41 \%$ for place dependence, place awareness, place identity, and place inherited respectively; for long-term residents, the respective response rates were $100 \%, 97 \%$, $87 \%$, and $93 \%$. Apart from the place dependence dimension, participants were able to skip sections. Response rates demonstrate the larger percentage of short-terms that had not developed particular bonds or relationships with areas in the city. Additional information on the number of drawn polygons, the ratio of polygon per participant as well as the number of polygons drawn entirely outside the city is found on Table 3.

\begin{tabular}{lllccc} 
& & drawn polygons & total polygons & ratio polygons/participant & polygons outside the city \\
\cline { 3 - 6 } Place dependence & short-term & 92 & 165 & 1.8 & 3 \\
& long-term & 73 & & 2.43 & 3 \\
\hline \multirow{2}{*}{ Place awareness } & short-term & 66 & 128 & 1.29 & 5 \\
& long-term & 62 & \multirow{2}{*}{108} & 2.07 & 5 \\
\hline \multirow{2}{*}{ Place identity } & short-term & 50 & & 0.98 & 2 \\
\hline \multirow{2}{*}{ Place inherited } & long-term & 58 & \multirow{2}{*}{83} & 0.68 & 2 \\
& short-term & 35 & & 1.6 & 6 \\
\hline
\end{tabular}

Table 3: Information on the number of drawn polygons for each dimension and participant group.

\subsection{Overlay and hotspot analysis}

Figure 2 displays the maps for each dimension of sense of place and participant group, as well as for the combined dimensions and participants altogether. Alongside the results of the hotspot analysis, we built maps containing the distribution of polygon overlap 
scores and the identification of places in the city that scored significant collective sense of place (Figure 3). High values of place dependence for short-terms entirely embodied the Alameda campus of the Instituto Superior Técnico (IST), a well-known institution of the University of Lisbon. This suggests that a large number of participants either studied or worked at IST at the time, as place dependence was strong not only in the campus itself but also in its surroundings. On the other hand, high values of place dependence for long-terms encompassed the Campolide campus of NOVA University Lisbon. In fact, according to the answers, some long-term residents reported living within the campus, more specifically in the university's student accommodation. As for place awareness, both groups reported high values concentrated in three distinct stretches of the city. This was likely due to the theoretical framework and consequently the survey questions, as they embedded facets of familiarity, knowledge and exploration, which in turn can represent different regions within the context of the city.

Values higher than $80 \%$ for place identity were found for short-term residents in the Arco do Cego Garden, nearby the Alameda Campus of IST. The neighborhood was designed as a social housing district and it was officially inaugurated in the 1930's [39]. The Arco do Cego Garden is a green area close to the IST campus, opened in 2005, renewed in 2017, and which in recent years has been a hotspot of the university students' nightlife, thus being an important place for students' social life [12]. Therefore, results suggest that short-terms (assumed to be mostly students and employees of the IST university) identified themselves with the garden, where significant social interactions might have taken place.

Both groups reported strong place identity towards areas in the neighborhoods of Anjos and Intendente. These regions are composed by a multilayered urban landscape characterized by a complex urbanistic history, a diverse multicultural environment due the high concentrations of immigrants, public policies that take into consideration the region's multi-ethnicity, as well as being a hotspot for cultural events, bars, and nightlife in general $[17,24,43]$. We also observed high values of place identity for short-term and long-term residents at the Gulbenkian Park, where gardens, museums, and libraries are found. The main museum and its surrounding gardens were officially inaugurated to the public in 1969 and since then, they have been a landmark in the city of Lisbon not only due to the cultural assets but also to the large urban green space [29]. The fourth and last dimension - place inherited - displayed its highest values for short-terms at the IST campus, the Alameda Garden as well as the Arco do Cego Garden, regions whose areas of functional attachment (place dependence) were also high for the same group. As for long-term residents, we found the strongest values of place inherited within the Campolide campus of NOVA University of Lisbon and surroundings. According to the results, the dimension was the least developed for short-term residents and it was, alongside the remaining dimensions, concentrated around the IST campus area.

\subsection{Spatial metric and Jaccard's index}

The Spatial Efficiency metric (SPAEF) scores range from $-\infty$ to 1 , where 1 represents an identical spatial pattern. Table 4 shows the results of SPAEF and its associated parameters in the comparison of the distribution of each dimension between short-terms and longterms. The dimension of place awareness scored the highest value whereas place inherited had the lowest score. We also present in Table 5 the selected areas' extent and their corresponding Jaccard's index score, which ranges from 0 to 1 , where 1 represents identical spa- 


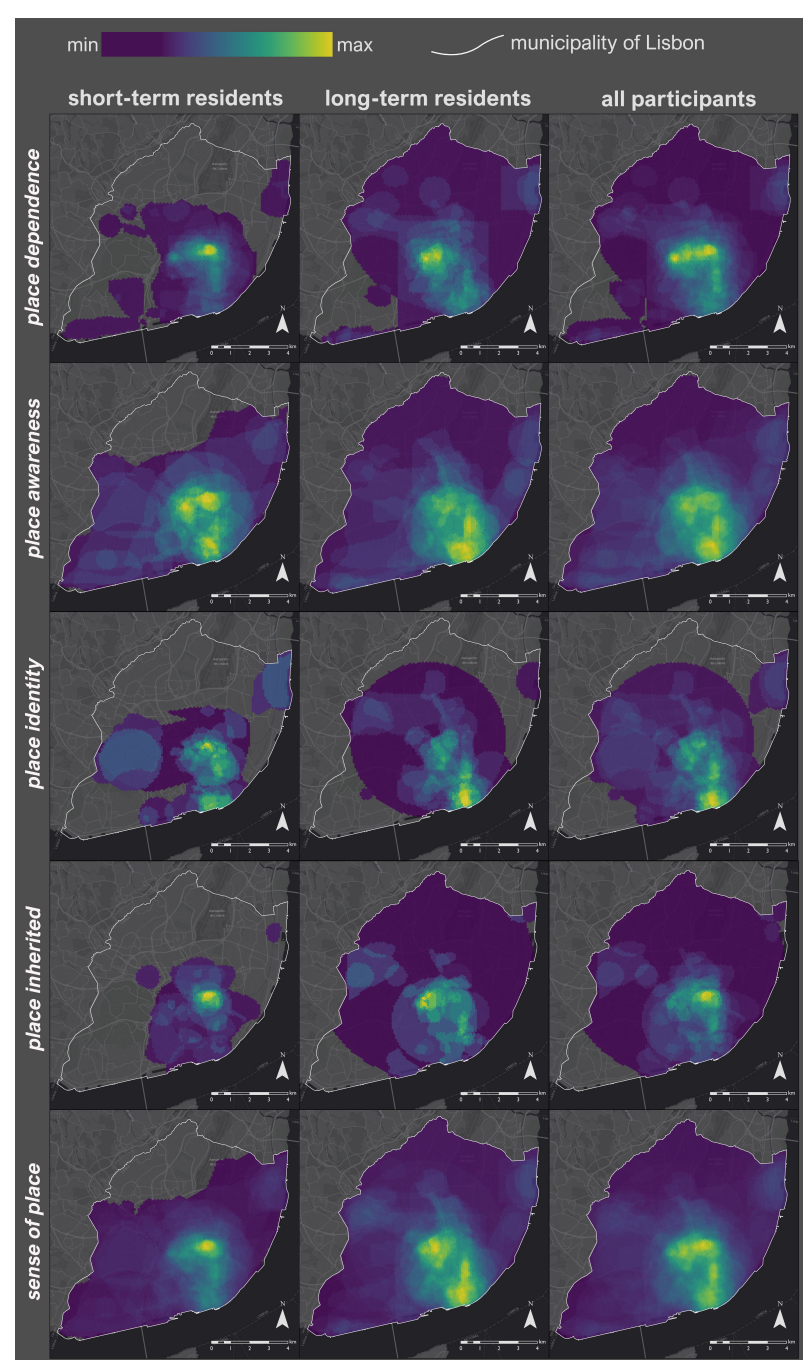

Figure 2: Normalized overlap values of the distribution of sense of place and its dimensions within the city of Lisbon.

tial concurrence. Furthermore, as previously mentioned, we applied the SPAEF metric to compare the spatial similarity between the dimensions of sense of place within each participant group (Table 6). Overall, SPAEF results demonstrated that the spatial distribution of the different facets of the construct are more geographically congruent or coincident within long-term residents. Place inherited yielded the lowest values of correlation between dimensions for both groups, yet for long-term residents the correlations were higher. Results of SPAEF and Jaccard's indices for long-term residents' dimensions are consistently higher, showing a higher similarity trend between dimensions within this participant group.

We identified the most similar distribution of collective sense of place between participant groups as being for the place awareness dimension. As for place identity, SPAEF 


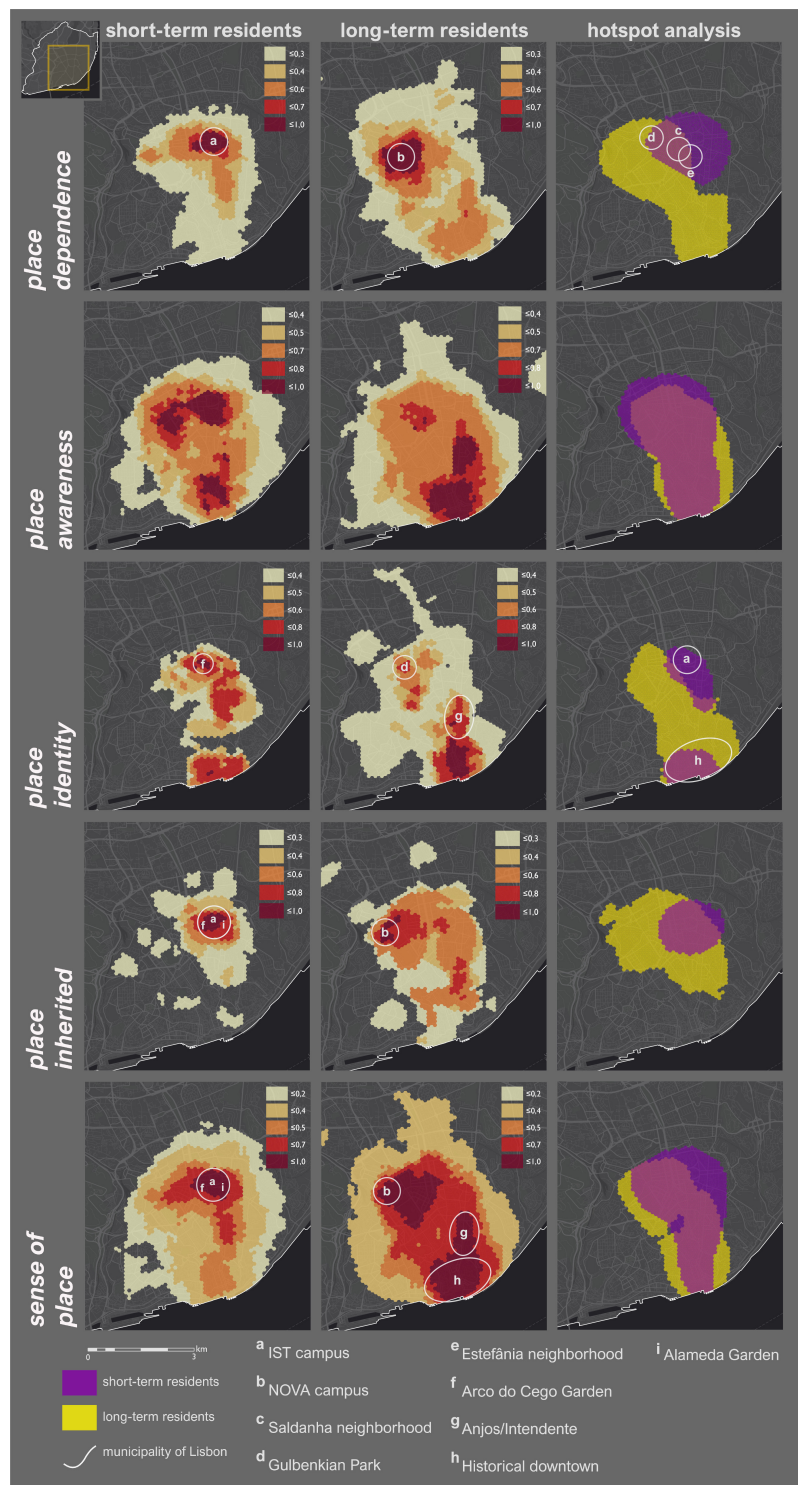

Figure 3: Distribution of overlap values higher than the upper quartile, distribution of the hotspot areas and places identified with high values of collective sense of place.

and Pearson correlation scored the second highest values. However, Jaccard's index values suggest a considerable dissimilarity between participant groups. This is confirmed by the maps and suggests that although the overall pattern and intensity of place identity for both groups are similar, the spatial extent and location of high values are distinct. The place dependence dimension scored the second lowest Pearson correlation value and SPAEF metrics. In addition, overall extents of long-term residents' sense of place dimensions were twice as large as short-term residents', although area similarity for hotspots' distributions 
yielded low values. Finally, scoring the lowest SPAEF and Pearson correlation, place inherited was the most dissimilar dimension between groups, also confirmed by respective areal overlaps. In general, areal extent values of dimensions were consistently higher for long-term residents and the areal overlap between groups (Jaccard's index) of the upper quartile areas decreased from place dependence towards place inherited.

\begin{tabular}{lcccc} 
& \multicolumn{4}{c}{ short-term vs. long-term residents } \\
\cline { 2 - 5 } & Place dependence & Place awareness & Place identity & Place inherited \\
\hline SPAEF & 0.11 & 0.61 & 0.51 & -0.53 \\
CC & 0.49 & 0.77 & 0.62 & 0.42 \\
CV & 1.68 & 1.29 & 1.28 & 2.37 \\
hmatch & 0.75 & 0.87 & 0.88 & 0.63 \\
\hline
\end{tabular}

Table 4: Spatial Efficiency metric (SPAEF); Pearson correlation (CC); Ratio of coefficient of variation $(\mathrm{CV})$; and histogram overlap (hmatch) between participant groups for each dimension of sense of place.

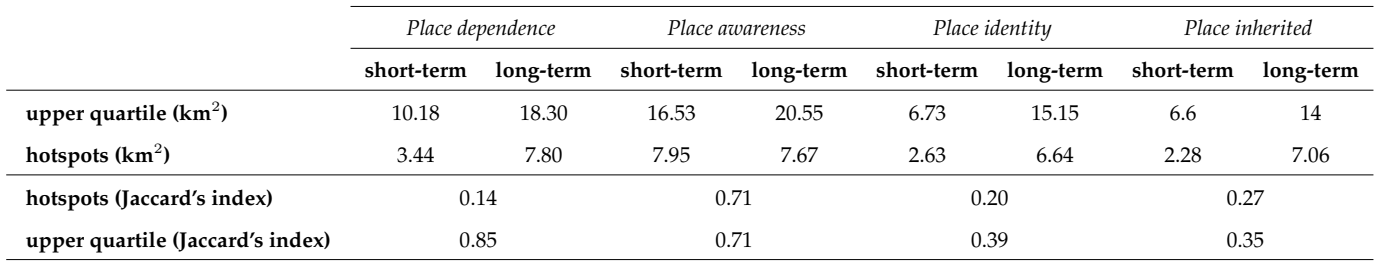

Table 5: Extent of selected areas and their Jaccard's similarity index for each dimension of sense of place: area with scores higher than the upper quartile and areas of $99 \%$ confidence hotspots.

\section{Discussion}

\subsection{Length of residence}

We interpreted the comparisons between participant groups and the relationships between the dimensions of sense of place within each group in Table 7 . Based on the quantitative results, we briefly outlined the main findings to act as our starting point for further discussion and contextualization. In addition to the interrelationships described in Table 7, the survey response rates provided an initial understanding on the influence of the length of residence on contributing to the intensification or the emergence of specific person-place bonds in the city: short-term residents skipped questions more often than long-term residents. Overall, individuals that had been living more than one year in the city felt sense of place across larger areas. The literature has pointed out several reasons behind this phenomenon, such as the role of affordances in allowing residents to perceive and interact with their surroundings [46], or the relationships with constructs such as social capital and sense of community in intensifying sense of place [21]. In the latter case, social activities, connections and interactions are developed and solidified over time, which strengthens the relations with places where social ties are established. Furthermore, this influence might be 


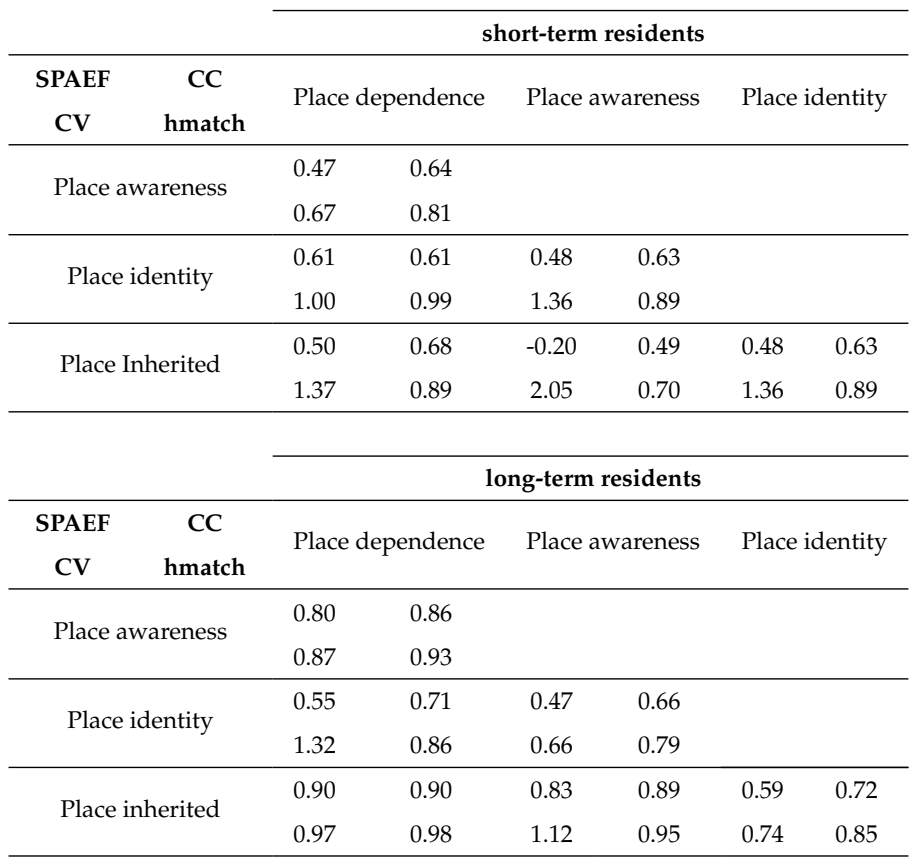

Table 6: Spatial Efficiency metric (SPAEF); Pearson correlation (CC); Ratio of coefficient of variation $(\mathrm{CV})$; and histogram overlap (hmatch) between each dimension of sense of place within short-term residents (top) and long-term residents (bottom).

regarded as bi-directional, since time within a city intensifies sense of place, which in turn encourages individuals to take part in more activities and expand their social network [47]. In our case, although we have not explicitly considered the social capital construct in the analysis, the dimension of place inherited embedded aspects of social ties, and the results obtained showed that this particular bond was considerably less developed among shortterm residents.

The spatial relationship between sense of place and social capital has in fact been exploited through the lenses of GIScience by researchers [2,4]. However, we have explored only the sense of place construct framed within the context of non-native residents, considering how different dimensions distinguish themselves between groups and across Lisbon. The intricate spatial characteristics collected through the survey and following analysis suggest the complex interplay of time, perception-action processes, geographical space, social ties and the built environment not only in maturing people's relationships with places, but also in shaping their spatial dimension. More importantly, our results are able to demonstrate how components of sense of place are spatially distinguishable when comparing groups with different lengths of residence, in accordance with non-spatial approaches that dealt with similar research objectives [22].

Regardless of possible moderators, we observed how length of residence might expand the geographical distribution of the person-place relationships. Long-term residents establish cognitive, affective, and behavioral interactions in more places and with more intensity, as time allows to physically explore the city [21]. Moreover, long-term residents' functional 
attachment (place dependence) was found to be stronger towards the historical downtown, while for short-term residents the bond was found mainly around the IST campus. Longterm residents might had been engaged in activities regarding leisure or entertainment based on more matured preferences, such as in the context of the youth-oriented nightlife in the city downtown [42] (see Figure 3).

The place dependence dimension distinguished the groups in two different university areas: the Campolide campus of NOVA University Lisbon and the Alameda campus of IST. These campuses acted as main places of routine-education, work or residence-for the participants. The resulting sampling profile was therefore biased towards individuals who were assumed to be mostly university students, researchers and employees, although we developed our framework aiming at collecting and analyzing sense of place from nonnative residents in general. Nonetheless, we did observe the influence of length of residence on sense of place (larger areas) when comparing both participant groups, which is in accordance with previous research $[18,48]$ and confirms, through the spatial perspective, that the variable is one of the key factors in the development of the construct. Furthermore, by obtaining the spatial dimension of the construct through a map-based survey we were able to obtain results that are in line with observations made in the literature within the context of our sampling bias. For instance, Chow and Healey [11] revealed how students transitioning from home to university actually developed different facets of sense of place within a 5-month period, influenced by new social ties. In fact, a significant percentage of short-term residents in our study have reported the existence of affective relationships with places in the city. The existence of different sense of place dimensions for short-terms distributed across the city suggests that sense of place can be fostered through processes considered to be immediate (perception-action) as well as longer-term (social capital, rootedness) at the same time [46].

\subsection{Relationships between dimensions}

Although long-terms reported experiencing sense of place at broader regions in the city, the spatial similarity between functional attachment and the feeling of belonging was shared between groups: collective place dependence of both short-terms and long-terms were highly correlated with the places where they also reported strong place inherited. The most significant areas included the two university campuses. Regardless of the strength of these bonds, both groups seemed to have developed social ties or feelings of rootedness where they carried out most of their routine-based activities. Another similar relationship found within groups is the low correlations between place inherited and place identity, suggesting that for both groups, places that were related to their self-expression or selfidentity were not spatially associated with places to where they had developed aspects of belonging, rootedness and social ties. According to Bernando and Palma-Oliveira [7], the dimensions of place identity is strongly influenced by social identity, which might indicate that in the case of non-native residents, identification with places is spatially distinguishable by areas where cultural and social aspects resemble their home countries or towns, mostly in terms of the presence of local communities. 
Table 7: Interpretation of the similarities and differences found between participant groups and between dimensions of sense of place.

\begin{tabular}{|c|c|c|c|c|c|c|c|c|}
\hline & \multicolumn{2}{|c|}{ Place dependence } & \multicolumn{2}{|c|}{ Place awareness } & \multicolumn{2}{|c|}{ Place identity } & \multicolumn{2}{|c|}{ Place inherited } \\
\hline & short-term residents & long-term residents & short-term residents & long-term residents & short-term residents & long-term residents & short-term residents & long-term residents \\
\hline $\begin{array}{l}\text { short-term vs. long-term } \\
\text { residents }\end{array}$ & \multicolumn{2}{|c|}{$\begin{array}{l}\text { Concentration found at the different university } \\
\text { campuses. In addition, the bond was stronger and } \\
\text { broader across the city for long-term residents. This } \\
\text { group also felt stronger place dependence towards } \\
\text { the historical downtown. The distribution of high } \\
\text { values of place dependence for long-term residents } \\
\text { was more heterogeneous. }\end{array}$} & \multicolumn{2}{|c|}{$\begin{array}{l}\text { For both groups, concentration in three regions of the } \\
\text { city. Overall, the spatial similarity was the highest. } \\
\text { Nonetheless, higher values of place awareness were } \\
\text { found at the historical dowtown for short-terms, } \\
\text { including a higher number of landmarks. The } \\
\text { dimension was felt to a larger extent across Lisbon in } \\
\text { the case of long-term residents. }\end{array}$} & \multicolumn{2}{|c|}{$\begin{array}{l}\text { While short-terms had two distinct high-value areas, } \\
\text { long-term residents' bond was broader and } \\
\text { contiguous. They scored the second-highest } \\
\text { similarity between groups. High values were found } \\
\text { at places around the campus for short-terms while } \\
\text { long-terms reported higher values towards the } \\
\text { downtown, multi-ethnic neighborhoods and parks. }\end{array}$} & \multicolumn{2}{|c|}{$\begin{array}{l}\text { The least similar between the groups. High values } \\
\text { were found at the university campuses. Overall, long } \\
\text { terms reported this bond at a much larger extent. } \\
\text { While short-terms mainly felt place inherited around } \\
\text { the campus, long-terms also scored broader and } \\
\text { stronger values towards landmarks and } \\
\text { neighborhoods. }\end{array}$} \\
\hline Place dependence & \multicolumn{2}{|c|}{$\mathrm{NA}$} & $\begin{array}{l}\text { Relationship suggests } \\
\text { that short-terms felt like } \\
\text { exploring places not } \\
\text { necessarily associated } \\
\text { with routine-based } \\
\text { places. }\end{array}$ & $\begin{array}{l}\text { Relationships suggests } \\
\text { that short-terms were } \\
\text { familiar with and aware } \\
\text { of the places of routine- } \\
\text { based activities. }\end{array}$ & $\begin{array}{l}\text { High spatial similarity } \\
\text { suggests that short- } \\
\text { terms generally } \\
\text { identified themselves } \\
\text { with places of routine- } \\
\text { based activities. }\end{array}$ & $\begin{array}{l}\text { Spatial similarity was } \\
\text { not as high as others, } \\
\text { suggesting that matured } \\
\text { personal preferences } \\
\text { were not necessarily } \\
\text { associated with routine- } \\
\text { based places. }\end{array}$ & $\begin{array}{l}\text { High spatial similarity } \\
\text { suggests that places of } \\
\text { routine were oftentimes } \\
\text { places they felt stronger } \\
\text { emotional attachment. }\end{array}$ & $\begin{array}{l}\text { High spatial similarity } \\
\text { suggests that places of } \\
\text { routine were oftentimes } \\
\text { places they felt stronger } \\
\text { emotional attachment. }\end{array}$ \\
\hline Place awareness & & & \multicolumn{2}{|c|}{$\mathrm{NA}$} & $\begin{array}{l}\text { High spatial similarity, } \\
\text { suggesting that places } \\
\text { chosen to be explored } \\
\text { were associated with self. } \\
\text { expression and personal } \\
\text { preferences. }\end{array}$ & $\begin{array}{l}\text { Low spatial similarity } \\
\text { between dimensions. } \\
\text { The dimension was the } \\
\text { most distinct within } \\
\text { long-terms, suggesting } \\
\text { the development of } \\
\text { matured preferences. }\end{array}$ & $\begin{array}{l}\text { Lowest spatial similarity } \\
\text { suggests that places } \\
\text { where short-terms } \\
\text { enjoyed exploring were } \\
\text { not associated with } \\
\text { areas they felt emotional } \\
\text { attachments. }\end{array}$ & $\begin{array}{l}\text { High spatial similarity } \\
\text { suggests long-term } \\
\text { residents were } \\
\text { emotionally connected } \\
\text { to places they were } \\
\text { familiar with. }\end{array}$ \\
\hline Place identity & & & & & \multicolumn{2}{|c|}{$\mathrm{NA}$} & $\begin{array}{l}\text { Similarity was not } \\
\text { significant. Places where } \\
\text { short-terms identified } \\
\text { themselves were not } \\
\text { necessarily associated } \\
\text { with places where they } \\
\text { developed stronger } \\
\text { sentiments. }\end{array}$ & $\begin{array}{l}\text { Similarity was not } \\
\text { significant. Places where } \\
\text { long-terms identified } \\
\text { themselves were not } \\
\text { necessarily associated } \\
\text { with places where they } \\
\text { developed stronger } \\
\text { sentiments. }\end{array}$ \\
\hline
\end{tabular}


Results also showed that the most dissimilar relationships between dimensions was between place awareness and place inherited for short-term residents, while the correlation was higher for long-terms. Based on the interrelationships described in Table 7, we studied how components of place awareness can spatially distinguish participants groups based on the concepts of familiarity and exploration. Familiarity might have been more related to long-term residents' areas to which they were strongly attached, associated with social ties and deeper connections. On the other hand, short-terms might have answered the map-based questions of place awareness while being more inclined to report the places where they enjoyed exploring, which are not necessarily associated with their places of attachment.

We also observed another aspect regarding the growth of sense of place which has been reported in the literature. When investigating how different dimensions of sense of place were felt by native and non-native residents, Hernández et al. [22] showed how they tend to coincide between natives, while different levels of development for each dimension were found within non-natives based on the length of residence. In our case, we could observe the higher spatial convergence between dimensions of sense of place for long-term nonnative residents. In other words, the spatial extent of different dimensions for long-term residents were more coincident within the group when compared to short-term residents.

\subsection{Final considerations and limitations}

How each dimension of sense of place is felt and developed through space and time will be different for each individual, and not all non-native residents will form the four aspects of the construct [52]. Nonetheless, when looking at the spatial distributions and similarities collectively, we came across relationships between groups and dimensions that have been approached in the literature mostly in environmental psychology, yet have rarely been studied through geographic information systems and spatial analysis. Although placebased information consists of other factors apart from space, the spatial component still is an intrinsic element. In light of this, we conducted our analysis acknowledging that sense of place, while felt by people, is also a spatial phenomenon. The methods we used can be employed with other psychological and social constructs that have a relationship with space and place. Mendoza and Morén-Alegret [38] discussed several methods for studying migrants' sense of place and pointed out that GIS is a valid tool to help inputting another perspective into the complexity of this phenomena, being one avenue that enables an integrative approach not only in its methods but also in its users from different research fields.

While some researchers have showed that immigrant status is not a significant predictor of sense of place [18], others have argued that socio-demographic characteristics can influence the development of the construct towards new places of residence [52]. Nonetheless, the methodological framework that we applied can be implemented considering both non-native residents in general as well as our sampling bias represented by university students and employees. In the higher-education context of non-native residents, map-based surveys and further spatial analysis could be integrated into frameworks of transferring the acquired information into specific real-life applications. For instance, mobility centers can understand how their foreign students and staff perceive the city and therefore target and shape marketing waves, integration events, housing advertisement, and city information found on their websites. Collecting the spatial dimension of sense of place aids the 
identification of functional, behavioral, affective and symbolic place meanings of different areas within the city. Through considering both short-term and long-term processes of development of person-place bonds, architects and urban planners can model and predict how non-native residents will experience different neighborhoods and places. According to Raymond [46], designing healthier and more welcoming environments in the urban landscape fosters the development of social capital, place memories and cultural events. In addition, these aspects heavily influence on the decision of non-native residents to settle in the new city [50]. Therefore, a potential first step towards achieving these goals consists of mapping where non-native residents feel sense of place throughout their urban environment, not necessarily bounded to administrative units, districts or official neighborhoods.

As for limitations in the present work, they concern the conceptual framework and the survey procedure. First, the high degree of intertwining between dimensions inputs one layer of complexity. Second, the spatial distribution of the dimensions represented a static picture of the person-place relationships, which in reality is dynamic in time and space. Moreover, representational vagueness is intrinsically present. In this case, uncertainty not only stems from the qualitative-quantitative symbiosis and theoretical background, but also from the attempt to collect representative spatial data on the map-based platform. Lastly, as we have discussed previously, our sampling was biased towards a more specific non-native resident profile: based on the results, we assumed most of the participants either studied or worked at two universities in Lisbon. Future work can further investigate sense of place of non-native residents not only through broadening the sampling approach, but also through carrying out longitudinal studies, as well as enriching spatial information with in-depth interviews, geonarratives or even geo-ethnographic frameworks. In addition, future studies could quantitatively consider home range, different time of residence thresholds, nationalities and socio-demographic variables to unravel other spatial features of non-natives' development of sense of place.

\section{Conclusions}

Sense of place and its dimensions are not only shaped by the physical environment, but they are felt in space where individuals inhabit, have experiences and interact with. Therefore, extracting the spatial picture of where residents have functional and meaningful relationships with places in the urban context can provide information valuable not only for spatial planning, but also for further investigation of the social and psychological constructs that are intertwined with places. In this paper, we have studied how distinct facets of sense of place are spatialized differently across the city among two groups of non-native residents in Lisbon, which helped us visualize how length of residence influences the intensity of person-place bonds as well as their geographic distribution across the city. The conceptual and methodological framework applied in our study can be adapted within the context of GIScience to explore the spatial perspective of sense of place matured by different non-native residents' socio-demographic profiles and specific communities in Lisbon, as well as in other urban areas. In a broader picture, using GIS-based methodologies for place-based studies is a step towards unfolding a citizen-centered layer of the city, which can have applications in place-based marketing, tourism, place branding, location-based services, urban planning, and policy-making.

www.josis.org 


\section{Acknowledgments}

This work was supported by the Master of Science in Geospatial Technologies (Geotech), an Erasmus Mundus Joint Masters (EMJMD) consortium under the EU's Erasmus+ program.

\section{References}

[1] Acedo, A., Mendoza Silva, G., Painho, M., And Casteleyn, S. One tool to spatialize all: sense of place, social capital and civic engagement. In Societal geoinnovation: selected papers of the 20th AGILE conference on Geographic Information Science (2017), A. Bregt, T. Sarjakoski, R. Lammeren, and F. Rip, Eds.

[2] Acedo, A., Oliveira, T., Naranjo-Zolotov, M., and Painho, M. Place and city: toward a geography of engagement. Heliyon 5, 8 (2019), e02261. doi:10.1016/j.heliyon.2019.e02261.

[3] Acedo, A., Painho, M., And Casteleyn, S. Place and city: Operationalizing sense of place and social capital in the urban context. Transactions in GIS 21, 3 (2017), 503520. doi:10.1111/tgis.12282.

[4] Acedo, A., Painho, M., Casteleyn, S., And Roche, S. Place and city: Toward urban intelligence. ISPRS International Journal of Geo-Information 7, 9 (2018). doi:10.3390/ijgi7090346.

[5] Acedo, A., Santa, F., Painho, M., And Henriques, R. Do people develop activities at places in which citizens have a sense of place? In Geospatial Technologies for All: short papers, posters and poster abstracts of the 21th AGILE Conference on Geographic Information Science (2018), A. Mansourian, P. Pilesjö, L. Harrie, and R. von Lammeren, Eds., vol. 745, pp. 1049-1059.

[6] Baptista, L. V., Nofre, J., AND do Rosário Jorge, M. Mobilidade, cidade e turismo: pistas para analisar as transformações em curso no centro histórico de lisboa. Sociologia: Revista da Faculdade de Letras da Universidade do Porto Temático (2018), 14-32. doi:10.21747/08723419/soctem2018a1.

[7] Bernardo, F., and Palma-Oliveira, J. Place identity, place attachment and the scale of place: The impact of place salience. Psyecology 4, 2 (2013), 167-193. doi:10.1080/21711976.2013.10773867.

[8] BROWN, G. Mapping spatial attributes in survey research for natural resource management: Methods and applications. Society \& Natural Resources 18, 1 (2004), 17-39. doi:10.1080/08941920590881853.

[9] BROWN, G., AND RAYMOND, C. The relationship between place attachment and landscape values: Toward mapping place attachment. Applied Geography 27, 2 (2007), 89111. doi:10.1016/j.apgeog.2006.11.002.

[10] BRown, G., RaYmond, C. M., AND CORCORAN, J. Mapping and measuring place attachment. Applied Geography 57 (2015), 42-53. doi:10.1016/j.apgeog.2014.12.011. 
[11] ChOW, K., AND Healey, M. Place attachment and place identity: First-year undergraduates making the transition from home to university. Journal of Environmental Psychology 28, 4 (2008), 362-372. doi:10.1016/j.jenvp.2008.02.011.

[12] Coelho, R. O Jardim do Arco do Cego é o novo Bairro Alto dos estudantes. Diário de Notícias. https://www.dn.pt/sociedade/ o-jardim-do-arco-do-cego-e-o-novo-bairro-alto-dos-estudantes-5186944.html, 2016. Last Accessed January, 2020.

[13] CURrY, M. R. Discursive Displacement and the Seminal Ambiguity. The Handbook of New Media: Social Shaping and Consequence of ICT (2002), 502-517.

[14] Deutsch, K., Yoon, S. Y., AND Goulias, K. Modeling travel behavior and sense of place using a structural equation model. Journal of Transport Geography 28 (2013), 155-163. doi:10.1016/j.jtrangeo.2012.12.001.

[15] EhrKamp, P. Placing identities: Transnational practices and local attachments of turkish immigrants in germany. Journal of Ethnic and Migration Studies 31, 2 (Mar. 2005), 345-364. doi:10.1080/1369183042000339963.

[16] ESRI. Survey123 for ArcGIS. https://survey123.arcgis.com, 2021. Last Accessed January, 2020.

[17] Estevens, A., Cocola-Gant, A., Calvo, D. M., And Matos, F. As artes e a cultura nas práticas hegemónicas e alternativas na cidade de lisboa. o caso do largo do intendente1. Forum Sociológico, 35 (Dec. 2019), 9-17. doi:10.4000/sociologico.7826.

[18] Gallina, M., AND Williams, A. Variations in Sense of Place Across Immigrant Status and Gender in Hamilton, Ontario; Saskatoon, Saskatchewan; and, Charlottetown, Prince Edward Island, Canada. 241-252. doi:10.1007/s11205-014-0636-4.

[19] Gustafson, P. Roots and routes: Exploring the relationship between place attachment and mobility. Environment and Behavior 33, 5 (2001), 667-686. doi:10.1177/00139160121973188.

[20] Gustafson, P. Place attachment in an age of mobility. In Place Attachment : Advances in Theory, Methods and Applications, P. Manzo L.C., Devine-Wright, Ed. 2014, pp. 37-48.

[21] HAY, R. SENSE OF PLACE IN DEVELOPMENTAL CONTEXT. Journal of Environmental Psychology 18, 1 (1998), 5-29. doi:10.1006/jevp.1997.0060.

[22] Hernández, B., Carmen Hidalgo, M., Salazar-laplace, M. E., and Hess, S. Place attachment and place identity in natives and non-natives. Journal of Environmental Psychology 27, 4 (2007), 310-319. doi:10.1016/j.jenvp.2007.06.003.

[23] Hidalgo, M. C., And Hernández, B. Place attachment: Conceptual and empirical questions. Journal of Environmental Psychology 21, 3 (2001), 273-281. doi:10.1006/jevp.2001.0221.

[24] HORTAS, J. Intervenço urbana e cultura: entre a intenço e o impacto. O caso do largo do intentende Pina Manique em Lisboa. Master's thesis, Universidade Católica Portuguesa, 2016. doi:10400.14/22048.

www.josis.org 
[25] JANSKA, E., ČERMÁK, Z., AND WRIGHT, R. New immigrant destinations in a new country of immigration: Settlement patterns of non-natives in the czech republic. Population, Space and Place 20, 8 (2014), 680-693. doi:10.1002/psp.1824.

[26] Jenkins, A., Croitoru, A., Crooks, A. T., And Stefanidis, A. Crowdsourcing a collective sense of place. PLoS ONE 11, 4 (2016), e0152932. doi:10.1371/journal.pone.0152932.

[27] Jorgensen, B. S., AND STEDMAN, R. C. Sense of place as an attitude: Lakeshore owners attitudes toward their properties. Journal of Environmental Psychology 21, 3 (2001), 233-248. doi:10.1006/jevp.2001.0226.

[28] Koch, J., Demirel, M. C., And Stisen, S. The spatial efficiency metric (spaef): multiple-component evaluation of spatial patterns for optimization of hydrological models. Geoscientific Model Development 11, 5 (2018), 1873-1886. doi:10.5194/gmd-111873-2018.

[29] LAPA, S. Para que (nos) serve o museu? A génese do Museu Calouste Gulbenkian. Master's thesis, Universidade Nova de Lisboa, 2009. doi:10362/20085.

[30] LEWICKA, M. What makes neighborhood different from home and city? effects of place scale on place attachment. Journal of Environmental Psychology 30, 1 (2010), 35-51. doi:10.1016/j.jenvp.2009.05.004.

[31] LEWICKA, M. Place attachment: How far have we come in the last 40 years? Journal of Environmental Psychology 31, 3 (2011), 207-230. doi:doi.org/10.1016/j.jenvp.2010.10.001.

[32] LEWICKA, M. Place inherited or place discovered? agency and communion in people-place bonding. Studies in Psychology 34, 3 (2013), 261-274. doi:10.1174/021093913808295154.

[33] LEWICKA, M. In search of roots: Memory as enabler of place attachment. In Place Attachment : Advances in Theory, Methods and Applications, P. Manzo L.C., Devine-Wright, Ed. 2014, pp. 49-60.

[34] Malpas, J. Place and Experience: A Philosophical Topography. Cambridge University Press, 1999. doi:10.1017/CBO9780511487606.

[35] Manzo, L. C., And Perkins, D. D. Finding common ground: The importance of place attachment to community participation and planning. Journal of Planning Literature 20, 4 (2006), 335-350. doi:10.1177/0885412205286160.

[36] MARCU, S. Emotions on the move: belonging, sense of place and feelings identities among young romanian immigrants in spain. Journal of Youth Studies 15, 2 (Mar. 2012), 207-223. doi:10.1080/13676261.2011.630996.

[37] Mazumdar, S., Mazumdar, S., Docuyanan, F., and McLaughlin, C. M. Creating a sense of place: the Vietnamese-Americans and Little Saigon. Journal of Environmental Psychology 20, 4 (2000), 319-333. doi:10.1006/jevp.2000.0170. 
[38] MendozA, C., AND MorÉn-Alegret, R. Exploring methods and techniques for the analysis of senses of place and migration. Progress in Human Geography 37, 6 (2013), 762-785. doi:10.1177/0309132512473867.

[39] Mesquita, M. D. O bairro do arco do cego. paradigmas e contradiçes. Artitextos (2006), 93-100. doi:10400.5/1787.

[40] Nelson, L., AND Hiemstra, N. Latino immigrants and the renegotiation of place and belonging in small town america. Social \& Cultural Geography 9, 3 (2008), 319-342. doi:10.1080/14649360801990538.

[41] NG, C. F. Canada as a new place: the immigrant's experience. Journal of Environmental Psychology 18, 1 (Mar. 1998), 55-67. doi:10.1006/jevp.1997.0065.

[42] Nofre, J., Martins, J. C., Vaz, D., Fina, R., Sequera, J., And Vale, P. The 'pink street' in cais do sodré: urban change and liminal governance in a nightlife district of lisbon. Urban Research E Practice 12, 4 (Mar. 2018), 322-340. doi:10.1080/17535069.2018.1449010.

[43] Oliveira, N. A. A Lisboa cosmopolita e o fascánio da diversidade. Cidades 39, 39 (2019), 115-128. doi:110.15847.

[44] Pretty, G. H., Chipuer, H. M., And Bramston, P. Sense of place amongst adolescents and adults in two rural australian towns: The discriminating features of place attachment, sense of community and place dependence in relation to place identity. Journal of Environmental Psychology 23, 3 (2003), 273-287. doi:10.1016/S0272-4944(02)000798.

[45] Raymond, C. M., Brown, G., AND Weber, D. The measurement of place attachment: Personal, community, and environmental connections. Journal of Environmental Psychology 30, 4 (2010), 422-434. doi:10.1016/j.jenvp.2010.08.002.

[46] Raymond, C. M., Kyttä, M., And Stedman, R. Sense of place, fast and slow: The potential contributions of affordance theory to sense of place. Frontiers in Psychology 8 (Sept. 2017). doi:10.3389/fpsyg.2017.01674.

[47] Rollero, C., AND De Piccoli, N. Place attachment, identification and environment perception: An empirical study. Journal of Environmental Psychology 30, 2 (2010), 198205. doi:10.1016/j.jenvp.2009.12.003.

[48] SCANNEll, L., AND GIFFORD, R. Defining place attachment: A tripartite organizing framework. Journal of Environmental Psychology 30, 1 (2010), 1-10. doi:10.1016/j.jenvp.2009.09.006.

[49] SCANNELL, L., AND GIFFORD, R. The psychology of place attachment. In Environmental Psychology: Principles and Practice, R. Gifford, Ed. Optimal Books, 2014, pp. 272-300.

[50] SCANNELL, L., AND GIFFORD, R. The experienced psychological benefits of place attachment. Journal of Environmental Psychology 51 (2017), 256-269. doi:10.1016/j.jenvp.2017.04.001.

www.josis.org 
[51] Stedman, R. C. Is it really just a social construction?: The contribution of the physical environment to sense of place. Society \& Natural Resources 16, 8 (2003), 671-685. doi:10.1080/08941920309189.

[52] TrabKa, A. From functional bonds to place identity: Place attachment of polish migrants living in london and oslo. Journal of Environmental Psychology 62 (2019), 67-73. doi:10.1016/j.jenvp.2019.02.010.

[53] TuAn, Y. Space and Place: The Perspective of Experience. Minneapolis: University of Minnesota Press., 1977.

[54] TuAn, Y.-F. Space and place: Humanistic perspective. In Philosophy in Geography, S. Gale and G. Olsson, Eds. Springer Netherlands, Dordrecht, 1979, pp. 387-427. doi:10.1007/978-94-009-9394-5_19.

[55] VANClay, F. Place matters. In Making Sense of Place: Exploring Concepts and Expressions of Place Through Different Senses and Lenses, F. Vanclay, M. Higgins, and A. Blackshaw, Eds. National Museum of Australia Press, 2008.

[56] Wartmann, F. M., AND Purves, R. S. Investigating sense of place as a cultural ecosystem service in different landscapes through the lens of language. Landscape and Urban Planning 175 (2018), 169-183. doi:10.1016/j.landurbplan.2018.03.021.

[57] Williams, D., AND VASKE, J. The measurement of place attachment: Validity and generalizability of a psychometric approach. Forest Science 49 (12 2003), 830-840.

[58] Williams, D. R., AND Stewart, S. I. Sense of Place: An Elusive Concept That is Finding a Home in Ecosystem Management. Journal of Forestry 96, 5 (05 1998), 18-23. doi:10.1093/jof/96.5.18.

[59] WU, C.-H. An empirical study on the transformation of likert-scale data to numerical scores. Applied Mathematical Sciences 1 (01 2007), 2851-2862.

[60] Xie, H., BAO, J., AND Kerstetter, D. L. Examining the effects of tourism impacts on satisfaction with tourism between native and non-native residents. International Journal of Tourism Research 16, 3 (2014), 241-249. doi:10.1002/jtr.1922.

\section{Appendix}

\subsection{Data}

Data collected and analyzed in this study is available on DOI:10.17632/gdfsrb3cy4.1

\subsection{Survey}

Survey steps in English (left) and Portuguese (right). 


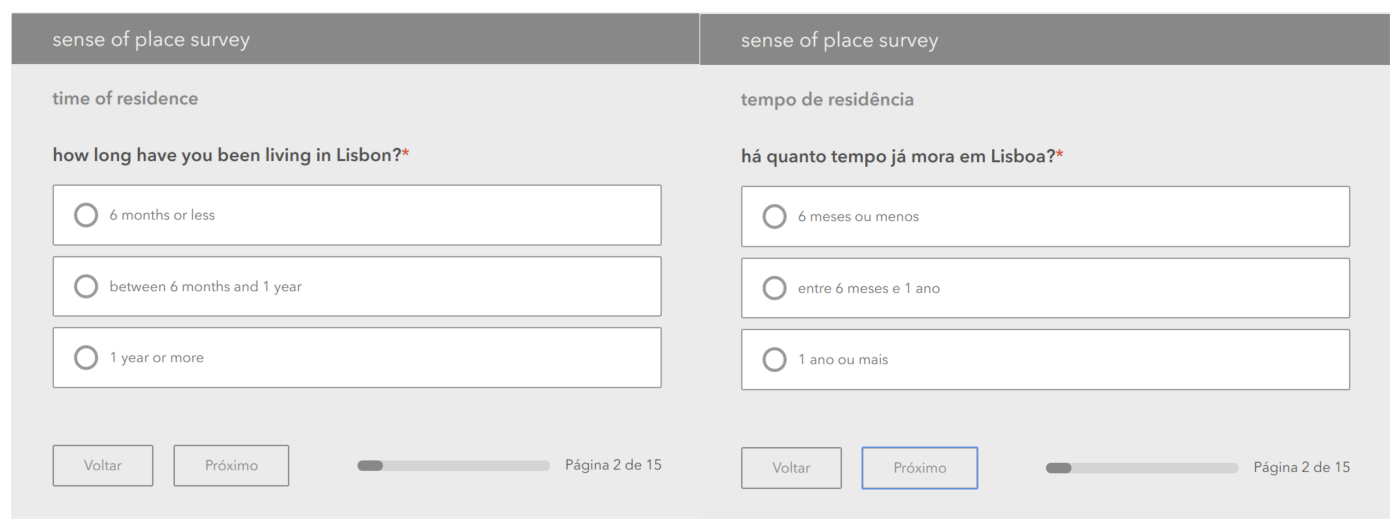

Figure 4: Time of residence question.

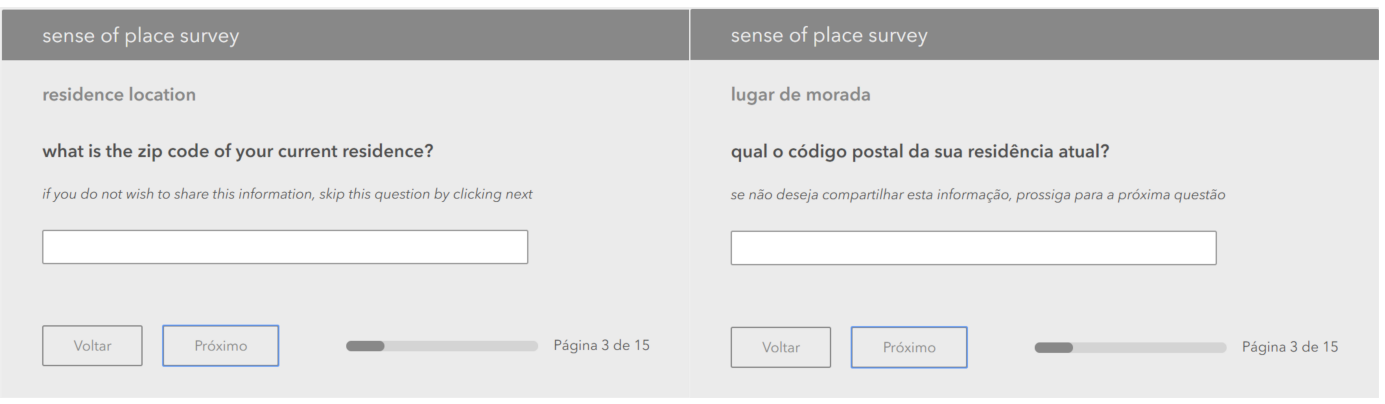

Figure 5: Residence location question.

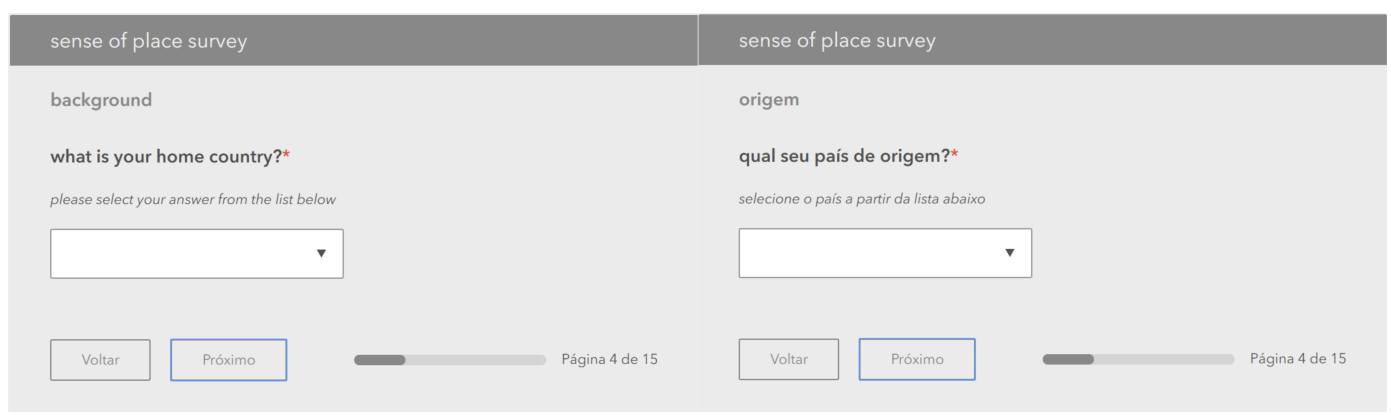

Figure 6: Country of origin question. 


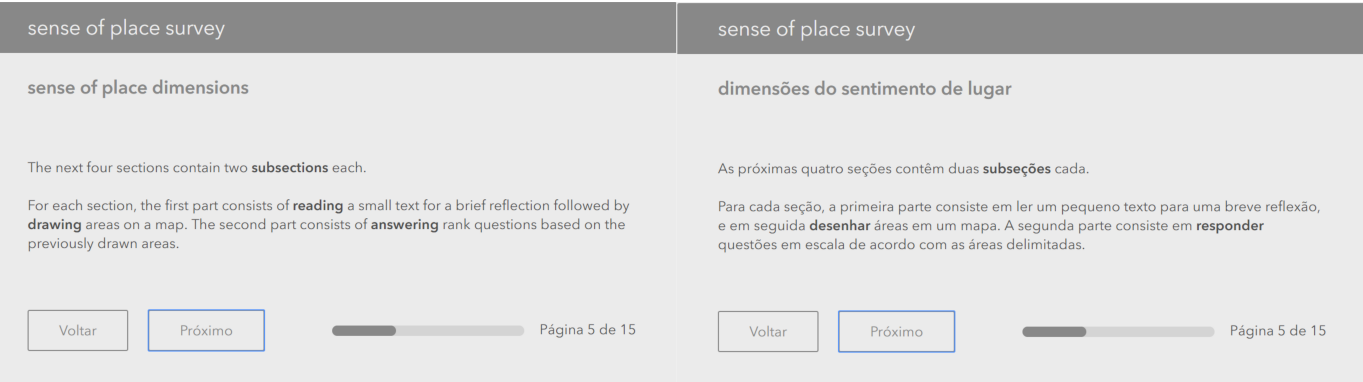

Figure 7: Brief explanation about following questions.

sense of place survey
section 1.1
$\begin{aligned} & \text { Think about the places in which you perform most of your daily tasks such as working, } \\ & \text { studying, doing groceries, going to the gym, etc. }\end{aligned}$
$\begin{aligned} & \text { In addition, also think about the best places for doing the activities you enjoy such as hobby, } \\ & \text { entertainment and leisure related activities. }\end{aligned}$

Figure 8: Introduction to place dependence section.

\begin{tabular}{|c|c|}
\hline sense of place survey & sense of place survey \\
\hline section 1.1 & seção 1.1 \\
\hline $\begin{array}{l}\text { Please use the map below to draw the areas that can answer at least one of the following } \\
\text { questions: }\end{array}$ & $\begin{array}{l}\text { Utilize o mapa abaixo para delimitar áreas que possam responder pelo menos uma das } \\
\text { seguintes perguntas: }\end{array}$ \\
\hline Where are the areas you perform most of your daily tasks? & Onde estão as áreas nas quais realiza a maioria das suas atividades diárias? \\
\hline Where are the best areas for doing the activities you like? & Onde estão as melhores áreas para realizar as atividades que gosta? \\
\hline instructions are below the map & instruçōes se encontram abaixo do mapa \\
\hline $\begin{array}{l}\text { important considerations } \\
\text { you are able to draw only one area per map tab } \\
\text { areas can overlap or coincide } \\
\text { one area can answer more than one question at the same time } \\
\text { you can draw multiple areas to answer the same question }\end{array}$ & $\begin{array}{l}\text { observaçôes importantes } \\
\text { apenas uma área pode ser desenhada a cada aba de mapa } \\
\text { áreas podem se sobrepor ou coincidir } \\
\text { uma área pode responder mais de uma questão ao mesmo tempo } \\
\text { mais de uma área pode ser desenhada para responder uma pergunta }\end{array}$ \\
\hline
\end{tabular}

Figure 9: Map-based question for place dependence. 


Sense of place survey
section 1.2
the places I chose are the most suitable for providing the conditions and
resources for my activities

Figure 10: Likert question for place dependence.

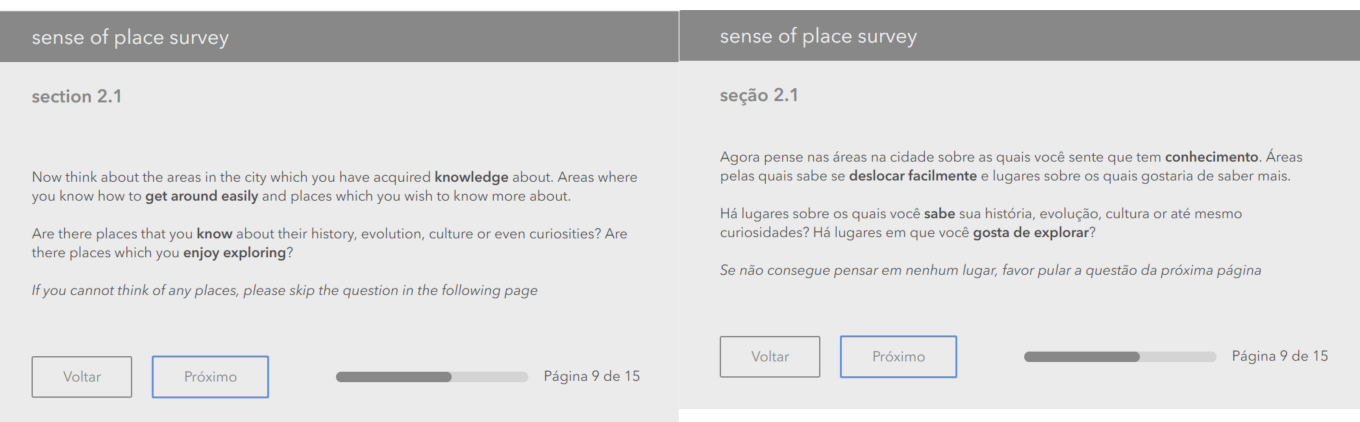

Figure 11: Introduction to place awareness section.

\begin{tabular}{|c|c|}
\hline sense of place survey & sense of place survey \\
\hline section 2.1 & seção 2.1 \\
\hline $\begin{array}{l}\text { Please use the map below to draw the areas that can answer at least one of the following } \\
\text { questions: }\end{array}$ & $\begin{array}{l}\text { Utilize o mapa abaixo para delimitar áreas que possam responder pelo menos uma das } \\
\text { seguintes perguntas: }\end{array}$ \\
\hline Where are the areas you know how to get around without using map applications? & Onde estāo as áreas nas quais sabe se deslocar sem utilizar aplicaçōes de mapa? \\
\hline Where are the areas you like to explore and discover or would like to do so? & Onde estão as áreas as quais gosta de explorar e desvendar ou gostaria de fazê-lo? \\
\hline instructions are below the map & instruçôes se encontram abaixo do mapa \\
\hline $\begin{array}{l}\text { important considerations } \\
\text { you are able to draw only one area per map tab } \\
\text { areas can overlap or coincide } \\
\text { one area can answer more than one question at the same time } \\
\text { you can draw multiple areas to answer the same question }\end{array}$ & $\begin{array}{l}\text { observaçôes importantes } \\
\text { apenas uma área pode ser desenhada a cada aba de mapa } \\
\text { áreas podem se sobrepor ou coincidir } \\
\text { uma área pode responder mais de uma questão ao mesmo tempo } \\
\text { mais de uma área pode ser desenhada para responder uma pergunta }\end{array}$ \\
\hline
\end{tabular}

Figure 12: Map-based question for place awareness. 


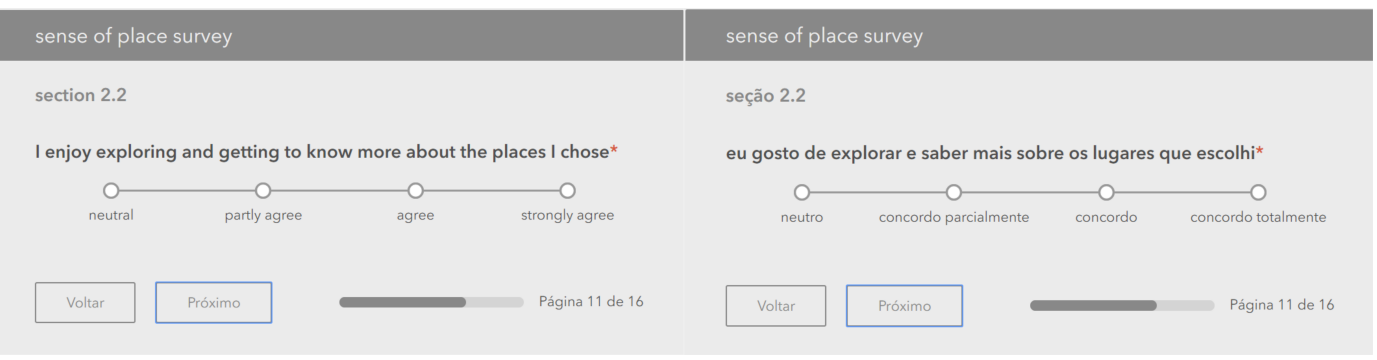

Figure 13: Likert question for place awareness.

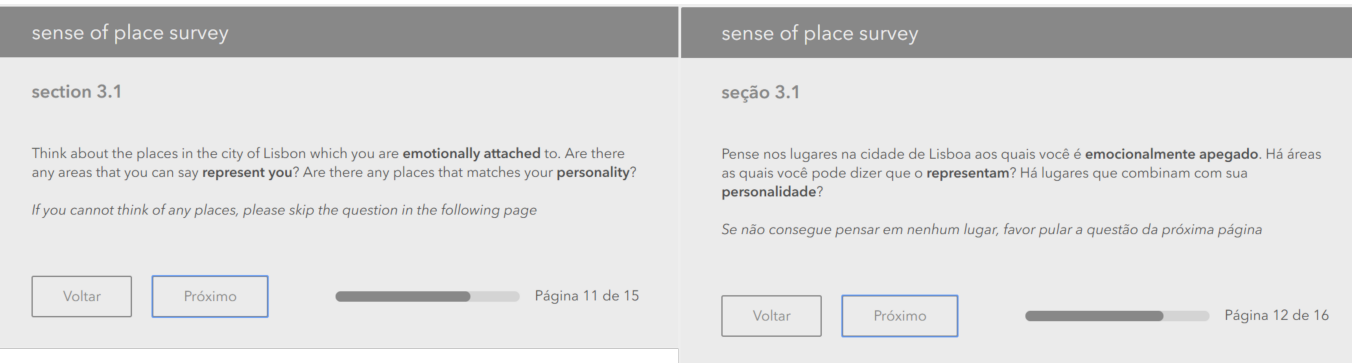

Figure 14: Introduction to place identity section.

\begin{tabular}{|c|c|}
\hline sense of place survey & sense of place survey \\
\hline section 3.1 & seção 3.1 \\
\hline $\begin{array}{l}\text { Please use the map below to draw the areas that can answer at least one of the following } \\
\text { questions: }\end{array}$ & $\begin{array}{l}\text { Utilize o mapa abaixo para delimitar áreas que possam responder pelo menos uma das } \\
\text { seguintes perguntas: }\end{array}$ \\
\hline Where are the areas you have a special bond with? & Onde estão as áreas com as quais você tem uma ligaçăo especial? \\
\hline Where are the areas that represent your lifestyle? & Onde estão as áreas que representam seu estilo de vida? \\
\hline instructions are below the map & instruçōes se encontram abaixo do mapa \\
\hline $\begin{array}{l}\text { important considerations } \\
\text { you are able to draw only one area per map tab } \\
\text { areas can overlap or coincide } \\
\text { one area can answer more than one question at the same time } \\
\text { you can draw multiple areas to answer the same question }\end{array}$ & $\begin{array}{l}\text { observaçōes importantes } \\
\text { apenas uma área pode ser desenhada a cada aba de mapa } \\
\text { áreas podem se sobrepor ou coincidir } \\
\text { uma área pode responder mais de uma questão ao mesmo tempo } \\
\text { mais de uma área pode ser desenhada para responder uma pergunta }\end{array}$ \\
\hline
\end{tabular}

Figure 15: Map-based question for place identity. 


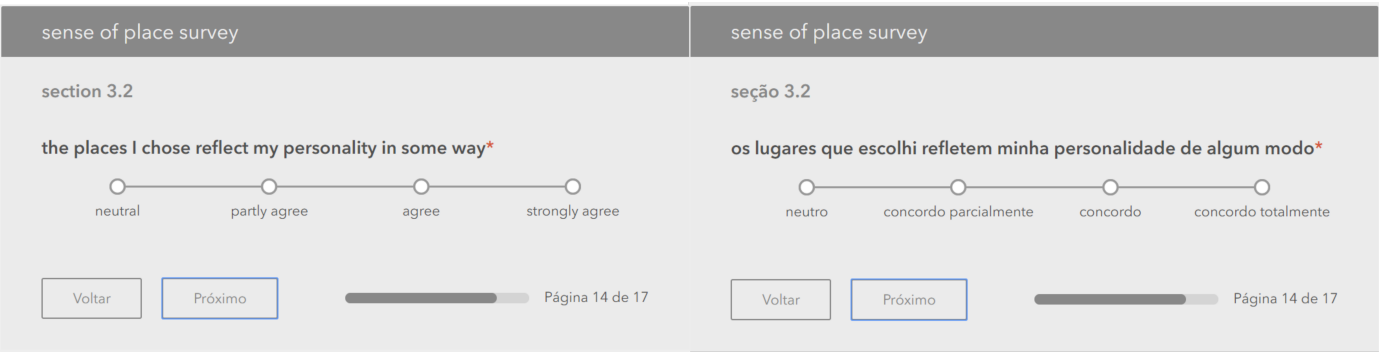

Figure 16: Likert question for place identity.

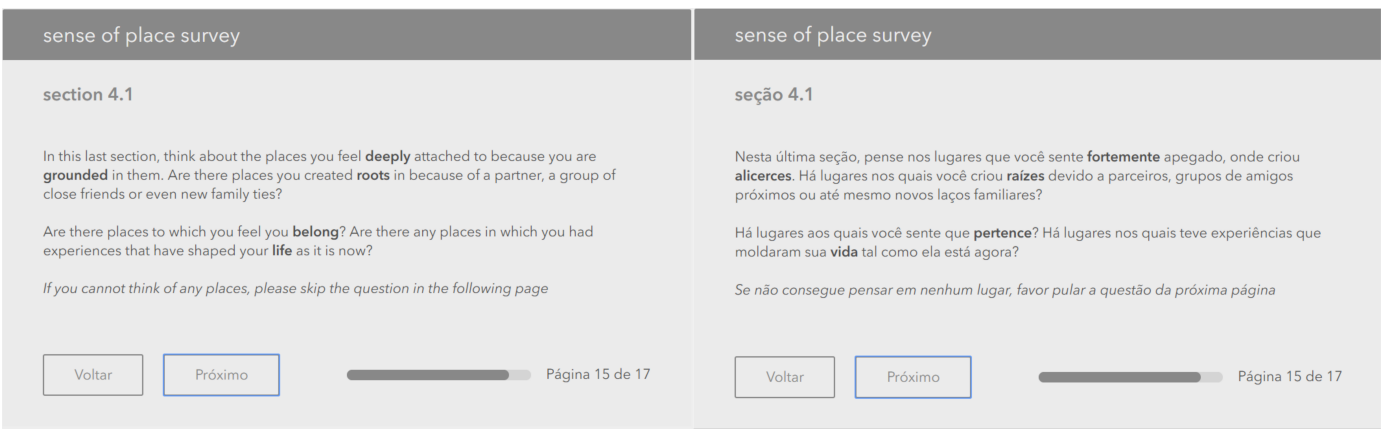

Figure 17: Introduction to place inherited section.

\begin{tabular}{|c|c|}
\hline sense of place survey & sense of place survey \\
\hline section 4.1 & seção 4.1 \\
\hline $\begin{array}{l}\text { Please use the map below to draw the areas that can answer at least one of the following } \\
\text { questions: }\end{array}$ & $\begin{array}{l}\text { Utilize o mapa abaixo para delimitar áreas que possam responder pelo menos uma das } \\
\text { seguintes perguntas: }\end{array}$ \\
\hline Where are the areas you feel you belong to because you created roots? & Onde estão as áreas às quais sente que pertence porque criou raízes? \\
\hline Where are the areas in which you had life-shaping experiences? & Onde estâo as áreas nas quais teve experiências que moldaram sua vida? \\
\hline instructions are below the map & instruçōes se encontram abaixo do mapa \\
\hline $\begin{array}{l}\text { important considerations } \\
\text { you are able to draw only one area per map tab } \\
\text { areas can overlap or coincide } \\
\text { one area can answer more than one question at the same time } \\
\text { you can draw multiple areas to answer the same question }\end{array}$ & $\begin{array}{l}\text { observaçōes importantes } \\
\text { apenas uma área pode ser desenhada a cada aba de mapa } \\
\text { áreas podem se sobrepor ou coincidir } \\
\text { uma área pode responder mais de uma questão ao mesmo tempo } \\
\text { mais de uma área pode ser desenhada para responder uma pergunta }\end{array}$ \\
\hline
\end{tabular}

Figure 18: Map-based question for place inherited. 


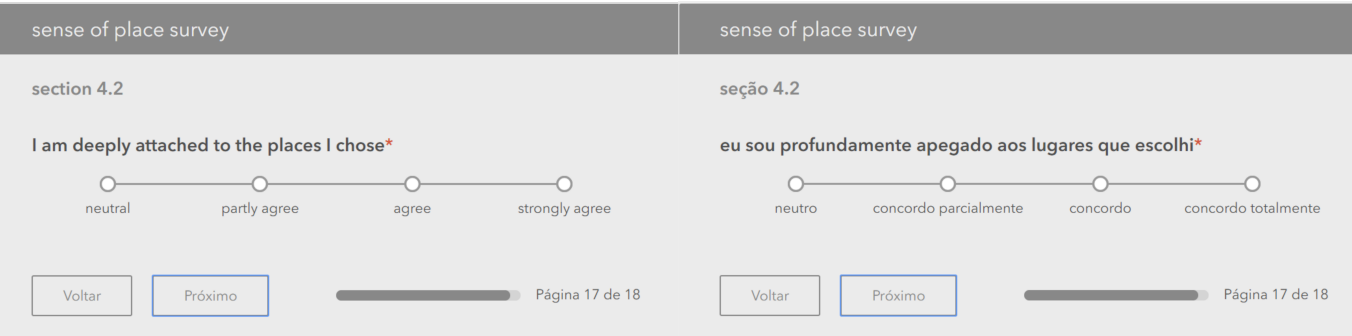

Figure 19: Likert question for place inherited. 